\title{
Reconhecimento da Força de Trabalho
}

\author{
Ferino, Valquiria da Silva; Melo, Rita de Cassia Siqueira de; Silva, Wania Aparecido da \\ Hospital das Clinicas - Instituto Central FMUSP — valquiria.ferino@hc.fm.usp.br
}

Introdução: Atualmente para a valorização profissional são utilizadas várias ferramentas, buscando o aperfeiçoamento do nível de desempenho dos colaboradores. Foi elaborado um Plano de Reconhecimento Profissional em um dos serviços de um hospital publico de grande porte. Este plano consiste em motivar e reconhecer a força de trabalho, agregando novas ideias e oportunidades para o colaborador. Objetivo: Melhorar continuamente o desempenho do colaborador por meio de estímulos pessoais que envolvem a sua auto estima. Aprimorar a qualidade do atendimento aos clientes internos e externos prestando um atendimento humanizado. Métodos: Elaboração de questionário de avaliação de desempenho operacional seguindo os itens: Responsabilidade das informações: Grau de confiabilidade das informações/atividades/serviços; Trabalho em Equipe: Capacidade de interagir e cooperar no compartilhamento de ideias, objetivos, atividades e soluções para atingir os objetivos institucionais; Participação na execução das tarefas: Atitudes referente a estar disponível para atender solicitações em atividades/serviços conforme necessário; Comprometimento: Esforço em prol da instituição, buscando atingir os objetivos organizacionais; Proatividade na execução das atividades: como compreender e responder às novas situações de trabalho, podendo exercer múltiplas atividades/serviços, inerentes à sua área de atuação; Aplicação do Conhecimento: Experiência no uso das ferramentas, métodos, procedimentos, softwares, equipamentos, entre outras, para melhorar o desenvolvimento das atividades em geral; Organização do Tempo e Trabalho - Prioridade: Atitudes em relação à administração de tempo e trabalho, considerando a assiduidade, a pontualidade, interrupções durante o período de trabalho; Comunicação: Capacidade de se relacionar de forma cordial com as pessoas dos diversos níveis hierárquicos; Avaliação escrita do Supervisor/Líder: o avaliador elabora um breve relatório, especificando o que seu funcionário agregou no desenvolvimento de sua atividade; Classificação: Após o preenchimento dos questionários efetuamos a classificação por pontos obtidos, sendo os funcionários com nota igual a 10 , recebem certificados de reconhecimento (Menção Honrosa); Reconhecimento: a entrega deste certificado ocorre através de um evento solene realizado em anfiteatro com a presença do Diretor Executivo, Diretor de Divisão, Chefes de Seção e representante do serviço de imprensa e ao final disponibilizamos um coffee break. Aplicação anual do questionário aos servidores das diferentes unidades. Cerimônia de premiação com entrega de certificados. Resultados: Colaboradores mais motivados demonstram melhora significativa no desempenho, tanto na execução de suas atribuições diárias, como no atendimento aos clientes internos e externos como mostram os Indicadores anuais. Conclusão: a liderança observou a necessidade de monitoramento das atividades dos seus colaboradores e elaborou esta ferramenta de avaliação para medir o desempenho dos mesmos, que tem demonstrado a formação de um pacto com a Instituição, um aumento na qualidade das informações prestadas aos seus clientes internos e externos. Os colaboradores que agem alem do contrato são homenageados.

Ferino, Valquiria da Silva; Melo, Rita de Cassia Siqueira de; Silva, Wania Aparecido da. Reconhecimento da Força de Trabalho. In: Anais do Congresso Internacional de Humanidades \& Humanização em Saúde [= Blucher Medical Proceedings, num.2, vol.1]. São Paulo: Editora Blucher, 2014. ISSN 2357-7282

DOI 10.5151/medpro-cihhs-10449 